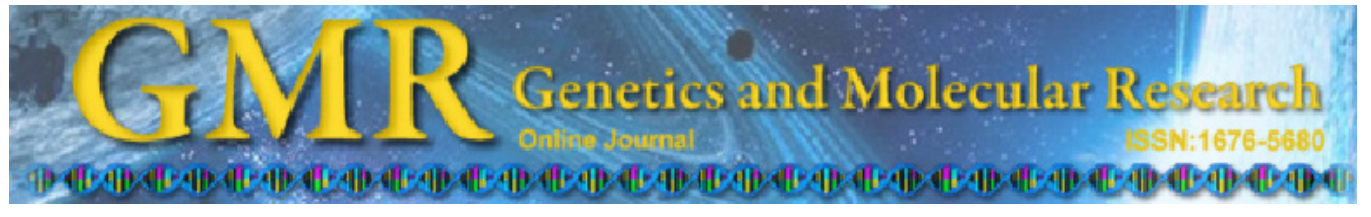

\title{
Elevated micronucleus frequencies in patients with pleural plaque secondary to environmental exposure to asbestos
}

\author{
M. Gövercin ${ }^{1}$, A.G. Tomatır ${ }^{1}$, F. Evyapan ${ }^{2}$, İ. Acikbas ${ }^{1}$, G. Coşkun ${ }^{2}$ and \\ B. $\mathbf{A k d a g}^{3}$ \\ ${ }^{1}$ Department of Medical Biology, Faculty of Medicine, Pamukkale University, \\ Denizli, Turkey \\ ${ }^{2}$ Department of Chest Diseases, Faculty of Medicine, Pamukkale University, \\ Denizli, Turkey \\ ${ }^{3}$ Department of Biostatistics, Faculty of Medicine, Pamukkale University, \\ Denizli, Turkey
}

Corresponding author: A.G. Tomatur

E-mail: tomatir@pau.edu.tr

Genet. Mol. Res. 13 (1): 598-604 (2014)

Received December 7, 2012

Accepted July 17, 2013

Published January 28, 2014

DOI http://dx.doi.org/10.4238/2014.January.28.5

\begin{abstract}
We examined genotoxic damage and frequency of micronuclei in people living in the Bekilli and Suller districts of Denizli city who had been diagnosed with pleural plaques as a result of environmental exposure to asbestos. Peripheral blood samples were obtained from 30 volunteer patients 59-86 years old who did not smoke or consume alcohol and who were diagnosed with calcified pleural plaques. We also examined 30 healthy controls with similar features, who also lived in downtown Denizli. Micronucleus frequencies, nuclear division index, and mitotic index were determined. Micronucleus frequency, nuclear division index, and mitotic index were significantly higher in patients who had been exposed to asbestos than in the controls. We conclude that asbestos had a genotoxic effect, resulting in an increase in micronucleus frequency and other changes in patients diagnosed with pleural plaques secondary to asbestos exposure.
\end{abstract}

Key words: Calcified pleural plaques; Environmental exposure; Asbestos; Genotoxicity test; Micronucleus assay 


\section{INTRODUCTION}

Asbestos is the overall term for the crystallized silicate mineral in fiber form found extensively in nature. Asbestos minerals found in the nature are separated into the two categories serpentine and amphibole. The most commonly used type of asbestos is chrysotile of the serpentine group (white asbestos). The amphibole category contains 5 different types of asbestos including crocidolite (blue asbestos), amosite (brown asbestos), anthophyllite, tremolite, and actinolite. Crocidolite, amosite and tremolite are the most harmful amphibole types of asbestos (Atabey, 2009). Turkey ranks among the first 10 countries in the world in terms of asbestos reservoirs. The amphibole asbestos formations around the Denizli-Bekilli region are within chlorite-tremolite-actinolite-sericite schists, colored bluish, white, greenish, $5-10 \mathrm{~cm}$ long and of the tremolite and actinolite type (WEB_8. ekutup.dpt.gov.tr/).

Diseases caused by environmental asbestos have been determined in many countries including Switzerland, Finland, Bulgaria, Greece, Pakistan, Cyprus, France, Russia, Japan, South Africa, China and Turkey (Hillerdal, 2002). Turkey has the highest prevalence of endemic pulmonary diseases associated with asbestos among several countries with extensive asbestos deposits in the world (Karakoca et al., 1997). Diseases associated with environmental asbestos have been reported from the rural areas of Konya, Diyarbakir, Sivas, Burdur, Cankiri, Yozgat, Eskisehir, Ankara and Denizli in Turkey (Şenyiğit et al., 2004; Barış et al., 1998). Several cases of mesothelioma and lung cancer secondary to asbestos and asbestosis have been reported from the city of Denizli and its surroundings (Bekilli, Cal, Suller, Tavas) (Evyapan et al., 2008). Pleuro-pulmonary diseases secondary to exposure to asbestos include diffuse pleural plaques, benign asbestos pleurisies, malign pleural mesothelioma, lung carcinoma, and asbestosis (Barış et al., 1998). Pleural diseases associated with asbestos could emerge 10-40 years after inhalation of this dust (Barış et al., 1995). Pleural plaques (PP) and diffuse pleural thickening (DPT) are among the most common diseases associated with asbestos (Miles et al., 2008).

Pulmonary and pleural diseases as well as genotoxic damage are observed at quite high rates in individuals exposed to environmental or industrial (occupational) asbestos via inhalation compared to the normal population (Dusinska et al., 2004). Several studies (Dopp et al., 1995) on the genotoxic effects of exposure to asbestos have examined micronucleus $(\mathrm{MN})$ frequency. Increased MN frequency is considered an indirect indicator of numerical and structural chromosomal abnormalities caused by certain agents. MN, which occurs during the mitotic division of the cell, is not part of the main nucleus and originates from complete chromosomes or acentric chromosome pieces. The technique of MN determination in lymphocyte cultures was first developed and performed by Stich et al. (1982) Asbestos formations are extensively found in our country, and their genotoxic effects and associated harmful effects on public health are assumed (Tug and Tug, 2005; Metintas et al., 2012) but have been examined only in a limited number of studies (Donmez et al., 1996; Tug et al., 2006; Donmez et al., 2007). The objective of this study was to investigate the genotoxic effects in lymphocytes using the cytokinesis-block micronucleus (CBMN) assay, in patients with pleural plaques who live in Bekilli and Suller districts of Denizli in Turkey and who have been environmentally exposed to asbestos.

\section{MATERIAL AND METHODS}

A total of 30 volunteer individuals consisting of 16 females and 14 males with a 
history of exposure to asbestos, 59-86 years old and living in the Bekilli and Suller districts of Denizli, were included in the study. They had been diagnosed with pleural plaques at the Department of Chest Diseases of Pamukkale University Medical School. The control group consisted of 30 healthy individuals including 16 females and 14 males between the ages of 37 and 84 years, with similar age, sex and socio-economic features, no history of drug intake, smoking or alcohol use in the last three months, and living in places without asbestos content in the soil. A questionnaire was administered to determine alcohol consumption, smoking, tea and coffee consumption habits, history of exposure to radiation, duration of living in the region with soil containing asbestos, and history of previous as well as current diseases. All subjects were examined and recruited by a specialist in thoracic diseases. Informed consent was obtained from all subjects. The study was approved by the Ethics Committee of Pamukkale University Medical School (30.06.2010-02). The study was conducted in accordance with the Declaration of Helsinki and local laws, depending on which afforded greater protection to the patients.

Peripheral blood samples from all individuals in both groups were collected in 5-mL sterile tubes containing 0.1-0.2 mL heparin and were immediately incubated in culture medium. Peripheral blood medium (Ham's F10, Biological Industries B101-090-1B) was used as the culture medium, along with $2.5 \mathrm{~mL}$ phytohemagglutinin (Biological Industries B1-12006-1H) per $100 \mathrm{~mL}$ medium, and stored at $-20^{\circ} \mathrm{C}$ following allocation into culture tubes. Twelve drops $(0.4 \mathrm{~mL})$ of blood samples were incubated in the culture tubes containing $5 \mathrm{~mL}$ medium at $37^{\circ} \mathrm{C}$, after discarding the first 3-4 drops. Incubation in 2 separate tubes was performed for each individual; tubes were stirred gently and stored in an incubator at $37^{\circ} \mathrm{C}$ for 72 h. Cytochalasin-B (AppliChem UN1544) was added at $44 \mathrm{~h}$. The CBMN assay was performed with certain modifications according to Fenech (2007). Culture tubes were removed from the incubator after the completion of $72 \mathrm{~h}$ and centrifuged at $1200 \mathrm{rpm}$ for $6 \mathrm{~min}$.

Next, culture tubes were treated with hypotonic solution $(0.1 \mathrm{M} \mathrm{KCl})$ and subjected to freshly prepared cold fixative (3:1, methanol (Merck):glacial acetic acid (Merck)), and preparations were prepared from the pellets obtained. Preparations were stained with newly prepared 6\% Giemsa (Merck) and left to dry after washing twice with distilled water. Dried preparations were dehydrated with xylol and stained and the slides coverslipped. Approximately 1000 binuclear cells were scored and MN frequency was determined in these preparations in both patient and control groups. In addition to these 1000 binuclear cells, trinuclear and tetranuclear cells, cells in metaphase, formations of nucleoplasmic bridge (NPB) and nuclear bud (NBud) were also examined under light microscopy and recorded. Nuclear division index (NDI) was also calculated (Eastmond and Tucker, 1989).

$$
\begin{gathered}
\mathrm{NDI}=1 \mathrm{~N}+(2 \times 2 \mathrm{~N})+(3 \times 3 \mathrm{~N})+(4 \times 4 \mathrm{~N}) / \text { total cell number } \\
N=\text { nucleus number }
\end{gathered}
$$

\section{Statistical analysis}

The SPSS 10.0 package was used for statistical analysis. Results are reported as mean \pm standard error (SE). Differences between means and medians were evaluated for significance using the independent samples $t$-test and Mann-Whitney U-test. Statistical significance was set at $\mathrm{P}<0.05$. 


\section{RESULTS}

Thirty volunteer individuals previously diagnosed at the Department of Chest Diseases of Pamukkale University Hospital with calcified pleural plaques after being environmentally exposed to asbestos, and 30 volunteer controls with no history of exposure to environmental asbestos were included in the study. Mean age of subjects with history of exposure to asbestos was $70.83 \pm 1.16$ and mean age of the controls was $53.97 \pm 2.12$. The patient group consisted of 16 females $(53.33 \%)$ and 14 males $(46.67 \%)$. In the patient group, ages of the females and males ranged 63-79 (mean \pm SE: $69.25 \pm 1.24)$ and 59-86 (mean \pm SE: $72.64 \pm 1.99)$, respectively. The control group consisted of 16 females (53.33\%) and 14 males (46.67\%). In the control group, ages of the females and males ranged 37-73 years (mean \pm SE: $52.94 \pm 3.01$ ) and 37-84 years (mean \pm SE: $55.14 \pm 3.05$ ), respectively. Total daily tea or coffee consumption of all female and male subjects was 0-3 cups in the patient group, and 2-7 cups in the control group. There was no history of smoking or alcohol consumption in the last 3 years in the patient group. Patients reported no daily exercises.

The following results were obtained comparing MN frequency in the peripheral blood lymphocyte cultures of subjects with or without history of exposure to asbestos. The numbers of binuclear, trinuclear and tetranuclear cells per 500 mononuclear cells were determined during the evaluation of binuclear cells in both groups. MN frequencies were rarely observed in the 3-nuclear and 4-nuclear cells of the subjects exposed to asbestos; no MN were observed in the 3-nuclear and 4-nuclear cells of the control subjects.

Mean MN frequency was $4.60 \pm 0.15$ in the patient group and $0.38 \pm 0.02$ in the control group. A significant difference in MN frequency was determined between the patient and control groups $(\mathrm{P}=0.0001)$ (Table 1$)$.

\begin{tabular}{lccc}
\multicolumn{2}{c}{ Table 1. Micronucleus $(\mathrm{MN})$, nuclear division index $(\mathrm{NDI})$, and mitotic index $(\mathrm{MI})$ values of the volunteers. } \\
\hline & Patients $(\mathrm{N}=30)$ & Controls $(\mathrm{N}=30)$ & P values* \\
\hline MN & $4.60 \pm 0.15$ & $0.38 \pm 0.02$ & 0.0001 \\
NDI & $1.22 \pm 0.01$ & $1.36 \pm 0.01$ & 0.0001 \\
MI & $5.80 \pm 0.45$ & $63.43 \pm 3.14$ & 0.0001 \\
\hline
\end{tabular}

*P values were calculated by using the independent samples $t$-test and Mann-Whitney U-test.

NDI values were lower in subjects exposed to asbestos compared to the controls. NDI values were calculated to determine any effects of asbestos on cell cycle. A significant difference was determined between patients and controls in terms of NDI values; NDI values were higher in the control group $(1.36 \pm 0.01)$ when compared with subjects with history of exposure to asbestos $(1.22 \pm 0.01 ; \mathrm{P}=0.0001)$ (Table 1$)$.

Mitotic index (MI) was decreased in subjects with history of asbestos exposure compared to the controls. A statistically significant difference was determined between patient $(5.80 \pm 0.45)$ and control groups $(63.43 \pm 3.14)$ in terms of MI level by the observed metaphase count $(\mathrm{P}=0.0001)$ (Table 1).

In addition, total NBP and NBud counts were determined in 1000 binuclear cells. Total NBP was 153 in the patient group, and 30 in the control group. Total NBud was 63 in the patient group, and 29 in the control group. 


\section{DISCUSSION}

Pleural plaques are known as biomarkers of exposure to asbestos (Miles et al., 2008). Genotoxic effects are known to emerge in humans following exposure to asbestos (Dusinska et al., 2004). Asbestos causes specific mitotic suppression and MN formation (Dopp et al., 1995).

In vitro studies have shown MI to be decreased after exposure to chrysotile mineral in Chinese hamster ovary cells by Hart et al. (1992), tracheal epithelium cells of Syrian hamster by Hesterberg et al. (1986), and pleural mesothelial cells of rats by Wydler et al. (1988) and Dong et al. (1994).

Donmez et al. (1996) reported that sister chromatid exchange frequency was increased in patients with pleural mesothelioma, lung cancer, pleural calcification and fibrosis, exposed to actinolite in Yassikaya village of Konya. Baran (2004) reported no difference in MN frequency but decreased NDI counts in Doğanlı village of Sivas. Likewise, Donmez-Altuntas et al. (2007) did not find any change in MN frequency in those exposed to the chrysotile/serpentine group (white asbestos) in Doğanlı village of Sivas.

In this study, we found an increase in MN frequency and decrease in MI in subjects exposed to the tremolite and actinolite type/amphibole group, indicating a possible genotoxic effect of this type asbestos. We also determined a similar significant decrease in NDI values in patients as by Baran (2004). The serpentine and amphibole group asbestos may cause a different damage level and decrease in NDI. However, chrysotile/serpentine group (white asbestos) damage could be repaired more easily than that of the asbestos/amphibole group and might not have caused increased MN frequency in the studies of Baran (2004) and Donmez-Altuntas et al. (2007).

MN frequency is affected by several factors. Certain studies have reported that MN frequency increases with age (Kazimirova et al., 2009; Fenech and Bonassi, 2011). In this study, there were no relationships between the MN frequency and age and sex in subjects diagnosed with pleural plaques secondary to asbestos.

Thierens et al. (1996) added controversy to the results by reporting that smoking did not significantly affect MN count. On the contrary, Rom (1998) found that exposure to asbestos plus smoking increased the risk of lung cancer in a synergistic manner. In this study, individuals in both patient and control groups did not indicate a smoking or drinking habit.

Several studies have reported that physical exercise decreases the frequency of MN (Huang et al., 2009). However, Schiffl et al. (1997) demonstrated that MN frequency was increased in healthy individuals performing strenuous exercise, particularly in the first $24 \mathrm{~h}$ of exercise. In this study, there were no subjects exercising regularly in either of the groups.

MN frequency was increased, whereas NDI and MI were decreased in patients with exposure to asbestos. These results further demonstrate the genotoxic effect of asbestos. Consequently, the inhabitants at risk of pleural diseases, genotoxic interactions and mesothelioma should be determined and followed up closely.

\section{ACKNOWLEDGMENTS}

Research supported by the Unit of Scientific Research Studies of Pamukkale University (Project \#2010-SBE-017). The authors are grateful to all volunteers for their participation in this study. 


\section{REFERENCES}

Atabey E (2009). Türkiye'de Asbest, Eriyonit, Kuvars ve Diger Mineral Tozlari ve Etkileri (In Turkey, Effects of Asbestos, Erionite, Quartz and Other Mineral Dusts) Ankara: Maden Tetkik ve Arama Genel Müdürlügü, Yer Bilimleri ve Kültür Serisi. 6; 7-16.

Baran M (2004). Çevresel Olarak Asbeste Maruz Kalan Kisilerin Lenfositlerindeki Sitogenetik Degisikliklerin Incelenmesi (Investigation of Cytogenetic Changes in Lymphocytes of People Who are Environmentally Exposed to Asbestos), Yüksek Lisans Tezi, MSc thesis, Kayseri: Saglik Bilimleri Enstitüsü; 25-32. Available at [http://sagens.erciyes.edu. tr/dergi/2004_2/tez_ozetleri.pdf].

Baris YI, Karakoca Y and Demir U (1995). Çevresel ve Mesleksel Akciger Hastaliklari (Environmental and Occupational Lung Diseases). In: Solunum Hastaliklari Temel Yaklasim (Basic Approach to Respiratory Diseases) (Baris YI, ed.). 2nd ed. Kent Matbaa, Ankara, 247-276.

Baris YI, Karakoca Y, Demir U (1998). Çevresel ve Mesleksel Akciğer Hastalıkları (Environmental and Occupational Lung Diseases). In: Solunum Hastalıkları (Respiratory Diseases). (Baris YI, ed.). 3rd edn. Atlas Kitapçl1ı, Ankara, 251-280.

Dong H, Buard A, Renier A, Levy F, et al. (1994). Role of oxygen derivatives in the cytotoxicity and DNA damage produced by asbestos on rat pleural mesothelial cells in vitro. Carcinogenesis 15: 1251-1255.

Donmez-Altuntas H, Baran M, Oymak FS, Hamurcu Z, et al. (2007). Investigation of micronucleus frequencies in lymphocytes of inhabitants environmentally exposed to chrysotile asbestos. Int. J. Environ. Health Res. 17: 45-51.

Donmez H, Ozkul Y and Ucak R (1996). Sister chromatid exchange frequency in inhabitants exposed to asbestos in Turkey. Mutat. Res. 361: 129-132.

Dopp E, Saedler J, Stopper H, Weiss DG, et al. (1995). Mitotic disturbances and micronucleus induction in Syrian hamster embryo fibroblast cells caused by asbestos fibers. Environ. Health Perspect. 103: 268-271.

Dusinska M, Collins A, Kazimirova A, Barancokova M, et al. (2004). Genotoxic effects of asbestos in humans. Mutat. Res. 553: 91-102.

Eastmond DA and Tucker JD (1989). Identification of aneuploidy-inducing agents using cytokinesis-blocked human lymphocytes and an antikinetochore antibody. Environ. Mol. Mutagen. 13: 34-43.

Evyapan BF, Ozpinar Y and Egri M (2008). Denizli Ilinde Çevresel Asbest Maruziyeti ve Solunum Sistemi Etkileri (Environmental Effects of Asbestos Exposure and Respiratory System in Denizli Province). Denizli: TUBITAK 107 S270 (SBAG-3763), 1-275.

Fenech M (2007). Cytokinesis-block micronucleus cytome assay. Nat. Protoc. 2: 1084-1104.

Fenech M and Bonassi S (2011). The effect of age, gender, diet and lifestyle on DNA damage measured using micronucleus frequency in human peripheral blood lymphocytes. Mutagenesis 26: 43-49.

Hart GA, Newman MM, Bunn WB and Hesterberg TW (1992). Cytotoxicity of refractory ceramic fibres to Chinese hamster ovary cells in culture. Toxicol. In Vitro 6: 317-326.

Hesterberg TW, Butterick CJ, Oshimura M, Brody AR, et al. (1986). Role of phagocytosis in Syrian hamster cell transformation and cytogenetic effects induced by asbestos and short and long glass fibers. Cancer Res. 46: 57955802.

Hillerdal G (2002). Asbestos-Related Pleural Disease Including Diffuse Malignant Mesothelioma. In: Pleural Diseases. Sheffield, European Respiratory Monograph (Loddenkemper R and Antony VB, eds.). 189-203.

Huang P, Huang B, Weng H, Nakayama K, et al. (2009). Effects of lifestyle on micronuclei frequency in human lymphocytes in Japanese hard-metal workers. Prev. Med. 4: 383-388.

Karakoca Y, Emri S, Cangir AK and Baris YI (1997). Environmental pleural plaques due to asbestos and fibrous zeolite exposure in Turkey. Indoor Built Environ. 6: 100-105.

Kazimirova A, Barancokova M, Dzupinkova Z, Wsolova L, et al. (2009). Micronuclei and chromosomal aberrations, important markers of ageing: possible association with XPC and XPD polymorphisms. Mutat. Res. 661: 35-40.

Metintas S, Metintas M, Ak G and Kalyoncu C (2012). Environmental asbestos exposure in rural Turkey and risk of lung cancer. Int. J. Environ. Health Res. 22: 468-479.

Miles SE, Sandrini A, Johnson AR and Yates DH (2008). Clinical consequences of asbestos-related diffuse pleural thickening: A review. J. Occup. Med. Toxicol. 3: 20.

Rom WN (1998). Asbestos Related Lung Disease. In: Fishman's Pulmonary Diseases and Disorders. 3rd ed. (Fishman AP, Elias JA, Fishman JA, Grippi MA, et al, eds.). Mc Graw Hill, New York, 877-891.

Schiffl C, Zieres C and Zankl H (1997). Exhaustive physical exercise increases frequency of micronuclei. Mutat. Res. 389: 243-246.

Senyigit A, Dalgic A and Kavak O (2004). Asbestin sagliga etkileri (Health Effects of Asbestos). Dicle Tip Dergisi 31: 48-52. 
Stich HF, Stich W and Parida BB (1982). Elevated frequency of micronucleated cells in the buccal mucosa of individuals at high risk for oral cancer: betel quid chewers. Cancer Lett. 17: 125-134.

Thierens H, Vral A and De Ridder L (1996). A cytogenetic study of radiological workers: effect of age, smoking and radiation burden on the micronucleus frequency. Mutat. Res. 360: 75-82.

Tug T and Tug E (2005). Asbest maruziyeti ve malign mezotelyama'da etiyopatogenez ve epidemiyolojik özellikler, tümör supresör gen iliskileri. (Etio-pathogenesis and Epidemiological Features in Asbest Exposure And Malignant Mesothelioma: The Role of Tumor Suppressor Genes: Review.). Türkiye Klinikleri. J. Med. Sci. 25: 436-444. Available at [http://www.turkiyeklinikleri.com/abstract.php?id=36258WEB_8. ekutup.dpt.gov.tr/]. Accessed May 29, 2011.

Tug E, Tug T, Elyas H, Coskunsel M, et al. (2006). Tumor suppressor gene alterations in patients with malignant mesothelioma due to environmental asbestos exposure in Turkey. J. Carcinog. 5: 23.

Wydler M, Maier P and Zbinden G (1988). Differential cytotoxic, growth-inhibiting and lipid-peroxidative activities of four different asbestos fibres in vitro. Toxicol. In Vitro 2: 297-302. 